\title{
Migránsok alkalmazásának megítélése munkavállalók körében
}

\section{The evaluation of the employment of migrants by employees}

\author{
K. DAJNOKI, P. M. KőMÍVES \\ Debreceni Egyetem, Gazdaságtudományi Kar, Vezetés- és Szervezéstudományi Intézet, \\ dajnoki.krisztina@econ.unideb.hu \\ Debreceni Egyetem, Ihrig Károly Gazdálkodás- és Szervezéstudományok Doktori Iskola, \\ komives.peter.miklos@econ.unideb.hu
}

\begin{abstract}
Absztrakt. A munkaerőpiaci szempontból veszélyeztetett munkavállalói csoportok sajátosságainak feltárása, illetve társadalmi-munkaerốpiaci integrációja mindig is kihívást jelentő feladat volt a szakemberek számára. A hazánkban is megjelenő migrációs hullám hatására a téma aktualitása 2015 nyarától még inkább fokozódott. Jelen tanulmányban „A migránsok befogadásának és munkaerőpiaci integrációjának humán erőforrás menedzsment kihívásai" címü kutatási program keretében arra kerestük a választ, hogy a munkavállalók hogyan viszonyulnak a migránsok munkaerőpiaci integrációjához. Célul tüztük ki, hogy feltárjuk, féltik-e a jelenlegi munkahelyüket, mely tényezők játszanak szerepet a migránsok foglalkoztatásában, valamint alkalmazásuk milyen pozitív, illetve negatív hatással járhat a társadalomra, gazdaságra. A kérdốives vizsgálati eredmények alapján a munkavállalók nem félnek attól, hogy a migránsok elveszik a munkahelyüket, ugyanakkor bizonytalanok abban a kérdésben, hogy alkalmaznának-e, illetve dolgoznának-e együtt migráns személlyel. A társadalomra, illetve gazdaságra gyakorolt hatás tekintetében egyértelmüen negatív attitüd figyelhetô meg.
\end{abstract}

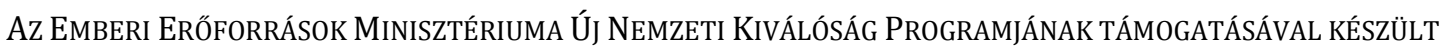

Abstract. The exploration of specifications of the employee groups endangered in the labour market, and their social and labour market integration have always been a challenging task for the professionals. As a result of the domestically also appeared migrant wave, the actuality of the topic has even more increased. In this study prepared in the framework of the research program "Human resource management challenges of the reception and labour market integration of the migrants" - we aimed to reveal the attitudes of employees about the labour market integration of the migrants. We have defined an objective to explore whether they are afraid of losing their current jobs, what factors influence the employment of the migrants and what kind of positive and negative effects they take on the society and economy. Based on the results of the survey we have found that employees are not afraid of migrants taking their jobs, still they are quite uncertain whether they would employ or work with a migrant person. Regarding the effect on the society and economy an unambiguous negative attitude was experienced.

\section{Supported through the New National ExCellence Program of the Ministry of Human CAPACItIes}




\section{Bevezetés}

Globális szinten évente százmilliók döntenek úgy, hogy hazájukat önszántukból elhagyják, annak reményében, hogy más országban jobb életkörülmények között tudnak majd élni vagy a hazájukban felmerülő veszélyek (súlyos emberjogi sérelem elkerülése, életének, testi-lelki épségének féltése) késztetik őket arra, hogy meneküljenek, új hazát keressenek, vagyis beszélhetünk önkéntes, illetve kényszer migrációról. Tanulmányunkban - annak tudatában, hogy a jog nem ismeri a migráns kategóriát - a migráns kifejezést gyűjtőfogalomként használjuk, azaz migránsnak tekintünk minden menekültet, menedékkérőt, menedékest és bevándorlót is függetlenül attól, hogy melyik Európai Unión kívüli országból érkezett és milyen céllal. A tanulmányban a migráns-érintettség kutatás részeredményeit ismertetjük, a migránsok foglakoztatásához kötődő eredmények feltárására fókuszálva.

\section{Szakirodalmi áttekintés}

„A XXI. század elöregedő Európájának egyik legfontosabb társadalmi kihívása az el- és bevándorlás, valamint a bevándorlók integrációja. Az, hogy egy társadalom mennyire tudja élvezni a migráció pozitív hatásait, és mennyire tudja minimalizálni az esetleges negatív mellékhatásokat, nagymértékben függ a társadalom tájékozottságától és előítélet-mentességétől." [8] A migrációt a migráns származási országának vagy célországának számos összefüggő gazdasági, politikai és társadalmi tényezője befolyásolja. A célországok a nemzetközi migrációt bizonyos esetekben a munkaerőpiaci hiány orvoslására használhatják fel, ugyanakkor ez önmagában azonban szinte biztosan képtelen visszafordítani a népesség elöregedésének az Európai Unió számos részén tapasztalható aktuális tendenciáját [5].

A migráns népességből csak egy részük jelenik meg a munkaerőpiacon. A legálisan hazánkban tartózkodó külföldiek közül is csak kisebb arányuk jelenik meg munkaerőpiai szereplőként, a nagyobb arányt az inaktívak teszik ki (eltartottak, gyerekek, idősek stb.). A munkaerő-migráció kapcsán három fontos munkaerőpiaci kérés merül fel. Egyrészt milyen a Magyarországra érkező migráns népesség szerkezete, gazdasági előnyszerzés vagy más cél motiválja őket. Másrészt, milyen a hazai munkaerőpiaci helyzetkép, globális vagy strukturális hiány jelentkezik, illetve a külföldi munkaerővel szemben milyen elvárások fogalmazódnak meg. Harmadrészt pedig a migrációs politika célja és hatása a migráns munkaerőpiacra [10]. Dunai (2017) alapján a Nemzetközi Munkaügyi Szervezet (IL0) 2016 év végén 232 millió migránst tartott számon, ebből 150 millió a munkavállalók, vendégmunkások száma. A többségük férfi. A legtöbb migráns dolgozót (az összesnek a felét) az Egyesült Államok és Nyugat-Európa foglalkoztatja, mindkét régióban külön-külön a világ gazdasági migránsainak körülbelül a negyede dolgozik.

A népszámlálási és adminisztrációs nyilvántartások adatai szerint a migráns népesség foglalkoztatási helyzete jobb, mint a magyaroké. A migráns népességnél a foglalkoztatási, mind az aktivitási ráta átlagosnál magasabb értéket mutat [17]. A harmadik országból érkező bevándorlók gazdasági 
aktivitása a hazai népességhez képest magas; az OEP 2009-es adatai alapján több mint 70 százalékuk aktív, míg a hazai társadalom esetében ez az arány mindössze 40 százalék [15].

Kincses (2015) alapján a szomszédos országokban született, Magyarországon elő 25-64 eves külföldi állampolgárok foglalkoztatási rátája 62,3\% volt 2001-ben és 71,4\% 2011-ben. 2011-ben a magyar lakónépesség hasonló adata 64,4\% volt, míg az összes 25-64 eves Magyarországon elő külföldi állampolgárra 70,2\%. Azaz a környező országok állampolgárai nagyobb aranyban dolgoznak, mint a lakónépesség vagy más külföldi állampolgárok hazánkban. Ugyanakkor nem szabad elfelejtkezni az illegális bevándorlókról sem, akik között magas a szakképzetlen dolgozók száma [19].

A fóbb munkapiaci pozíciókat az 1. táblázat összegzi. Az adatok alapján megállapítható, hogy a szerény lélekszámú, feltörekvő migráns csoportként definiált dél-kelet ázsiai fejlődő, valamint a közel-keleti és észak-afrikai országokból származók munkapiaci helyzete a legkedvezőbb, mivel vállalkozási hajlandóságuk, aktivitásuk, kvalifikáltságuk magasabb a magyarországi népesség átlagánál. A közelkeleti és észak-afrikai országokból érkezők között az aktívaknak mindössze negyede alapfokú vagy legfeljebb szakmunkás végzettségű (a határon túli szomszédos országokból érkező migránsok esetében ez az arány 37\%, a magyarországi aktív népességben 43\%). Az egyetemi végzettségűek aránya 28\% (a határon túli szomszédos országokból származók körében 18\%, a magyarországi aktív népességben 9\%)[11].

\begin{tabular}{|c|c|c|c|c|}
\hline \multirow[t]{2}{*}{ Bevándorló küldő régiója } & \multicolumn{3}{|c|}{ Dolgozó migránsok tevékenység szerint } & \multirow{2}{*}{$\begin{array}{c}\text { Munkanélküliségi } \\
\text { ráta }\end{array}$} \\
\hline & Alkalmazottak & Vállalkozók & Együtt & \\
\hline Külföldiek együtt & $90 \%$ & $10 \%$ & $100 \%$ & $7 \%$ \\
\hline \multicolumn{5}{|l|}{ ebböl } \\
\hline Határon túli országok & $93 \%$ & $7 \%$ & $100 \%$ & $9 \%$ \\
\hline $\begin{array}{l}\text { Dél-kelet ázsiai fejlődő } \\
\text { országok }\end{array}$ & $75 \%$ & $25 \%$ & $100 \%$ & $2 \%$ \\
\hline $\begin{array}{l}\text { Közel-keleti és észak- } \\
\text { afrikai országok }\end{array}$ & $84 \%$ & $16 \%$ & $100 \%$ & $8 \%$ \\
\hline Magyarország & $92 \%$ & $8 \%$ & $100 \%$ & $13 \%$ \\
\hline
\end{tabular}

1. táblázat: Az aktív migráns népesség kiválasztott csoportjainak és a hazaiaknak a munkapiaci pozíciója

(Forrás: Népszámlálás 2011, állampolgárság szerint definiált országcsoportok In: Hárs [11])

A hazai munkaerőpiacon munkát vállaló külföldiek többségének munkavállalási lehetősége Európai Unióhoz csatlakozást követően egyszerűsödött, ugyanakkor a harmadik országokból érkezők munkavállalása változatlanul engedélyköteles maradt [11]. A Dél-Alföldi Regionális Társadalomtudományi Kutatási Egyesület (2009) záró tanulmányában ismertetett kutatási eredményei alapján a harmadik országbeli állampolgárok, amennyiben a szükséges iratokat beszerzik, a magyar állampolgárokhoz hasonló esélyekkel rendelkeznek a munkaerőpiacon, sőt, amennyiben több nyelvet beszélő, jól képzett munkaerőről van szó, a külföldi nemzetiségét gyakran előnyként éli meg. Rédei (2007) alapján hazánkban a migráns népesség többsége magasabb iskolai végzettséggel rendelkezik, mint a magyar lakónépesség. 
Juhász et al. (2011) kutatási eredményei szerint a külföldi munkavállalók rugalmasabbak, mobilabbak és olcsóbban vállalnak munkát. A kutatás azt is vizsgálta, hogy a szakértők (munkavállalói érdekképviselet, vállalkozás, NFSZ, állami önkormányzati szerv, kutató, NGO) szerint milyen hatással van a magyar gazdaságra, társadalomra a külföldiek munkaerő-piaci részvétele. Az eredmények alapján a leginkább kiemelt pozitív hatás, az hogy így lehet betölteni a kevésbé vonzó, rosszul fizetett állásokat. A legjelentősebb negatív hatásnak azt tartották, hogy a külföldiek itthoni munkavégzése konzerválja a rossz munkakörülményeket, valamint hozzájárul az előítéletek növekedéséhez. Kincses (2015) alapján a globális migráció során a befogadó országokban általánosan tapasztalható negatív hatások hazánkban kevésbé jelentkeznek. A migrációnak a közvetlen népességpótló szerepe mellett pozitív gazdasági, társadalmi, demográfiai hatásai is vannak hazánkra, mivel a lakónépességhez képest a migránsokra a magasabb iskolázottsági szint, a fiatalabb korszerkezet, kevesebb munkanélküli, több foglalkoztatott jellemző.

A nemzetközi migráció előnyeit és hátrányait Piore (1979) duális elmélete és Simon (1984) neoklasszikus elmélete szerint a kibocsátó és fogadó országok szempontjából a 2. táblázat foglalja össze. Huzdik (2014) alapján „negatív hatásként jelenik meg a kibocsátó országnál az agyelszívás, a hatékonyság romlása, a képzett munkaerő lassú pótlása, valamint a felsőoktatásba történő állami beruházás (államilag támogatott képzések) lassan kerül pótlásra az elvándorlások miatt. Negatívum a fogadó ország felsőoktatása számára, hogy csökkenhet a képzett migránsok miatt a hazaiak érdeklődése a továbbképzés iránt, továbbá a kvalifikáltak nem látnak kifutási lehetőséget." Előnnyel jár a befogadó ország számára a kvalifikált migráns érkezése, mivel magas iskolai végzettségű, jól képzett munkavállalók épülnek be a gazdaságba, viszonylag gyorsan és ezáltal fokozódik a $\mathrm{K}+\mathrm{F}$ tevékenység. Több vállalkozás jöhet létre, a technológiai export anyag, tudás és know-how alapján nőhet [22].

\begin{tabular}{|c|c|c|c|}
\hline \multicolumn{2}{|c|}{ Kibocsátó ország } & \multicolumn{2}{|c|}{ Befogadó ország } \\
\hline Elöny & Hátrány & Elöny & Hátrány \\
\hline $\begin{array}{l}\text { - Fölös munkaerő } \\
\text { csökkenése } \\
\text { • Hazautalások } \\
\text { • Világméretekben } \\
\text { hosszú távon jólét } \\
\text { növekedés }\end{array}$ & $\begin{array}{l}\text { • Hátrahagyott } \\
\text { társadalmi tőke } \\
\text { • Tőkehozadék } \\
\text { csökkenése } \\
\text { • Népsűrűség/népesség- } \\
\text { nagyság externáliái } \\
\text { • Agyelszívás } \\
\text { - Világméretekben rövid } \\
\text { távon: adókiesés } \\
\text { • Szakismeret } \\
\text { • Politikai elonny: } \\
\text { „biztonsági szelep” }\end{array}$ & $\begin{array}{l}\text { • Műszaki-gazdasági } \\
\text { fejlődés: többlet } \\
\text { szakismeret révén } \\
\text { közvetlenül és többlet } \\
\text { (áru- szolgáltatás-) } \\
\text { kereslet révén } \\
\text { • Társadalmi-gazdasági } \\
\text { fejlődés előmozdítása: } \\
\text { többlet szakismeret } \\
\text { révén közvetve } \\
\text { • Többlet (munkaerő-) } \\
\text { kínálat révén } \\
\text { hiányszakmák } \\
\text { betöltése }\end{array}$ & $\begin{array}{l}\text { • Nincs bérverseny, mert } \\
\text { a „szekunder” } \\
\text { szektorban } \\
\text { foglalkoztatott, első } \\
\text { generációs } \\
\text { bevándorlók } \\
\text { „marginálisak” } \\
\text { (fokozottabban } \\
\text { manipulálhatók, } \\
\text { ellenőrizhetők) } \\
\text { • Verseny inkább } \\
\text { „primer” és } \\
\text { „szekunder” } \\
\text { szektorokon belül, } \\
\text { második stb. generáció } \\
\text { között. }\end{array}$ \\
\hline
\end{tabular}




\section{2. táblázat A migráció előnyei és hátrányai a kibocsátó és a befogadó országok szemszögéből}

(Forrás: [18, 21, 23])

Gyimóthy (2008) szerint a magasan képzett, tanulni vágyó, motivált bevándorló munkaerő, akiknek van korábbi szakmai tapasztalata, kulturális erőforrásaikkal gazdagítja a vállalat profilját. Idegennyelv-tudásukkal hozzájárulhatnak a szervezeti portfolió bővítéséhez. A menekültek megbecsülik a nehezen szerzett munkájukat, sokszor kitartóbbak és rugalmasabbak a munkában. Ez utóbbi tényezők jelentősége a globalizáció, illetve a gyorsan változó piaci környezet hatására egyre csak nő (Juhász, 2010). A migránsok sikeres szervezeti integrációja a teljesítményre is hatással van, mivel a nem megfelelő munkahelyi légkör gátló tényezőként hat (Gergely, 2015). Ezek ugyanis jelentős stresszt okozhatnak, úgynevezett teljesítőképességet negatívan befolyásoló stresszorok lehetnek [24].

Bördős et al. (2015) empirikus eredményei alapján a bevándorlás negatív hatása a hazai munkavállalók bérére vagy foglalkoztatottságának csökkenésére csak rövidtávon, illetve a hazai munkavállalók bizonyos csoportjainál mutathatók ki. Véleményük szerint középtávon (kb. 4-6 év múltán) a magyar munkavállalók számára a bevándorlás semleges vagy előnyös, mivel pozitívan hathat a befogadó ország átlagos bérszínvonalára. A Szerzők alapján ez két folyamatnak köszönhető. Egyrészt a vállalatok dinamikusan alkalmazkodnak a bevándorlás következtében kialakuló munkaerőkínálat növekedéshez, így az olcsóbbá váló képzetlen munkaerőt nagyobb mértékben felhasználó technológiákra váltanak. Másrészt, a bevándorlók által végzett viszonylag egyszerűbb munkákkal kiegészítő viszonyban álló komplex/szellemi munkakörök relatív értéke megnövekszik és a hazai munkavállalók ezekbe áramlanak, vagyis magasabb presztízsű, bonyolultabb kompetenciákat igénylő beosztásokba lépnek át, így a keresetük nő.

\section{Anyag és módszer}

“A migránsok befogadásának és munkaerőpiaci integrációjának humán erőforrás menedzsment kihívásai" című kutatási program célja egyfajta migráns-érintettségi vizsgálat lefolytatása, amellyel feltárható, hogy miként viszonyulnak a migráció jelenségéhez, illetve a migránsok munkavállalási törekvéséhez a munkaadók, munkavállalók és a leendő pályakezdők, milyen elképzelés, attitűd alakult ki bennük a jelenséggel kapcsolatban. Jelen tanulmány a munkavállalók körében végzett kutatás eredményeit ismerteti a foglalkoztatáshoz, munkavállaláshoz kötődő kérdésblokkra fókuszálva ( $\mathrm{n}=184)$. A kérdőívek begyưjtésénél nehézségbe ütköztünk a vizsgált témával szemben tanúsított alacsony válaszadási hajlandóság miatt, illetve nem segítette az adatok felvételezését az sem, hogy időtartama részben egybeesett az adott témát érintő nemzeti konzultációval. Az előbbiek miatt a kvótás mintavételezést kizártuk és hólabda módszerrel gyűjtöttük be az adatokat. A kérdőív összeállításánál a saját kérdések megfogalmazása mellett „A munkaerő-piaci integráció kihívásai Magyarországon - A harmadik országbeli munkavállalók beilleszkedésének esélyei és korlátai” című, 2011-ben készült kutatás (Juhász et. al, 2011) kérdőívének 3 kérdését vettük alapul, illetve bővítettük.

A demográfiai adatokról elmondható, hogy a válaszadók 29\%-a Kft-nél dolgozik, míg a második legnagyobb arányban 16-16\%-kal az egyéni vállalkozók és a zártkörű részvénytársaság munkavállalói vannak. Az önkormányzatnál dolgozók 9\%-ot, a civil szervezetek alkalmazottai 4\%-ot képviselnek a 
mintában. 3-3\% válaszadó betéti társaságnál, illetve az egészségügyi intézménynél dolgozik. A megkérdezettek 7\%-a az egyéb kategóriát jelölte meg, míg 2 fő a KKT-t, illetve 3 fó nem válaszolt a kérdésre. A szervezetek székhelye nyolc megyére oszlik szét (Hajdú- Bihar, Szabolcs-Szatmár-Bereg, Borsod-Abaúj-Zemplén, Békés, Jász-Nagykun-Szolnok, Heves és Pest). A legtöbb válaszadó (83 fő) Hajdú-Bihar megyében szervezetnél dolgozik, de jelentős a Szabolcs-Szatmár-Bereg megyéből érkezett kérdőívek száma is (57db), a két megye a vizsgált minta $76 \%$ át teszi ki. A vizsgált téma jellege miatt fontosnak tartottuk, hogy a szervezetek tulajdonosi hátterét is vizsgáljuk. Megállapítható, hogy a válaszadók 81\%-a magyar tulajdonban, 14\%-uk külföldi, míg mindössze 5 fő jelölte meg, hogy vegyes tulajdonban lévő szervezetnél dolgozik. A legtöbb válaszadó (61fő) a szolgáltató szektorban dolgozik. A második legmagasabb arányt a közszféra alkalmazottai teszik ki (41 fô), míg hasonló az aránya az iparban (26 fő) és a kereskedelemben dolgozó (23 fő) válaszadóinak.

A nemenkénti megoszlást tekintve a női nem szerepel nagyobb arányban a mintában (55\%), a férfi válaszadók száma 83 fő. A végzettség szerinti megoszlást az 1. ábra szemlélteti. Megállapítható, hogy a válaszadók egynegyede főiskolai, illetve Bsc/BA diplomával rendelkezik (45 fő). Ezt követi a szakközépiskolai végzettséggel rendelkezők aránya (33 fő), amit azonos arányban 16-16\%-ban a felsőfokú képesítéssel, illetve egyetemi diplomával rendelkezők aránya.

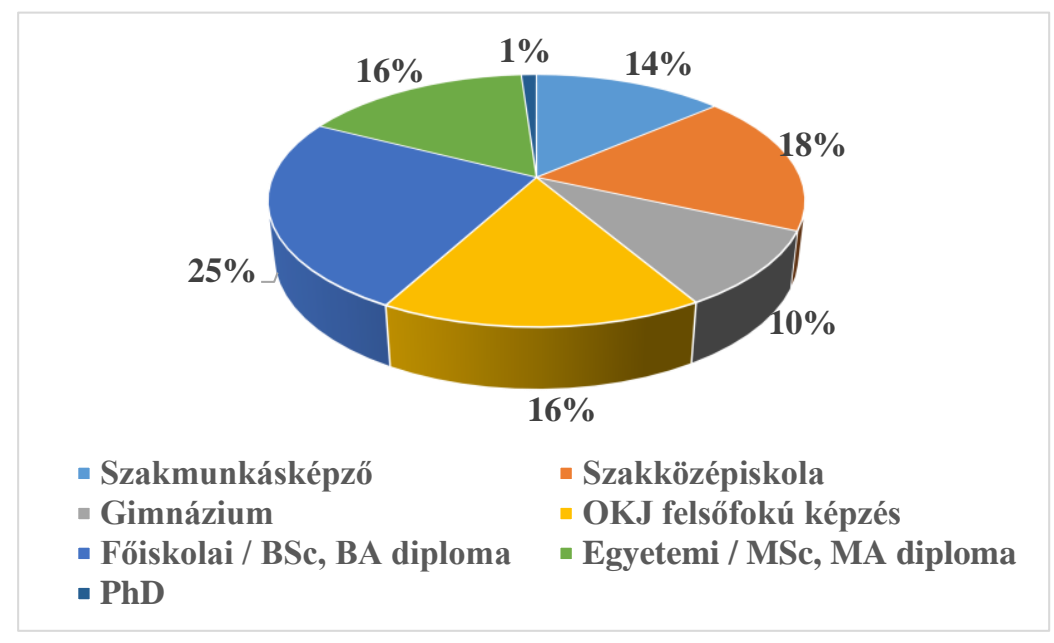

1. ábra A válaszadók végzettség szerinti megoszlása

\section{(Forrás: Saját adatgyüjtés)}

A válaszadók beosztását tekintve a minta közel kétharmadát a beosztottak teszik ki (2. ábra). A felsővezetők 10\%-ban vannak jelen a válaszadók között (19 fő), a középszintű vezetők aránya 14\% (25 fő), az alsó szintű vezetők pedig 12\%-ban képviseltetik magukat (22 fő). A beosztottak közül a szellemi foglalkozásúak szerepelnek nagyobb arányban a mintában (74fő), míg a fizikai dolgozók a minta közel egynegyedét teszik ki. 


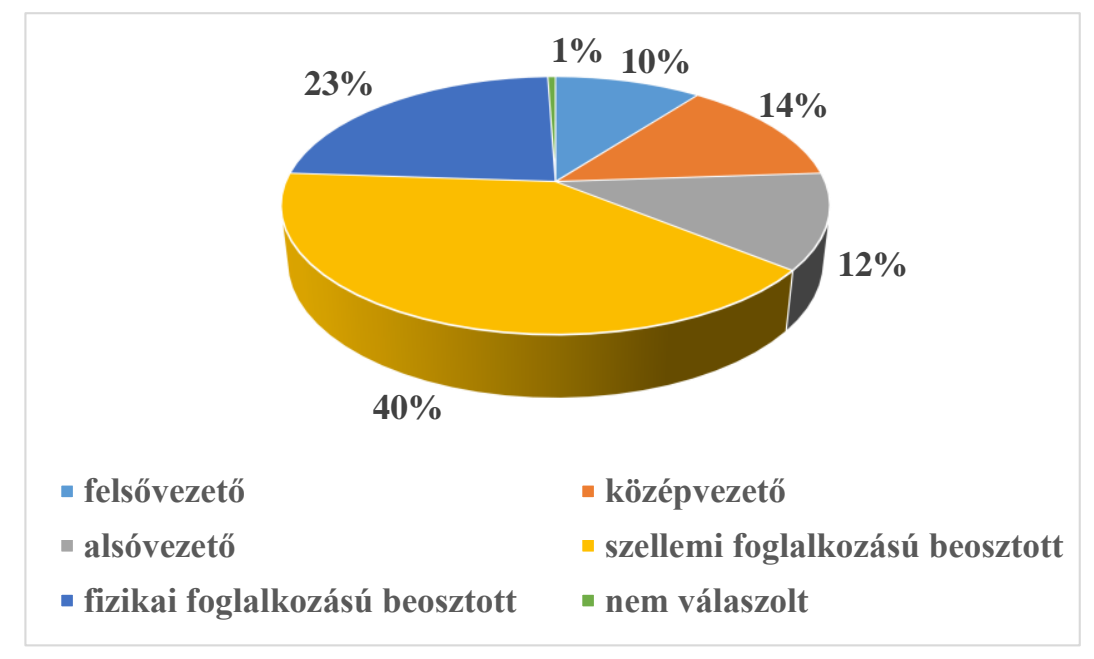

2. ábra A válaszadók megoszlása beosztás szerint

(Forrás: Saját adatgyüjtés)

A vizsgálatok során az érintett kérdésblokkban az alábbiakra kerestük a választ:

- Egyetért-e a válaszadó a migránsok munkaerőpiaci integrációjával?

- Fél-e attól, hogy a migránsok elveszik a munkalehetőséget?

- Dolgozna együtt migránssal, illetve szívesen lenne migráns kollégája szakmai mentora?

- Milyen tényezők játszanak szerepet a migránsok foglalkoztatásában?

- A migráns munkavállalók alkalmazása milyen pozitív, illetve negatív hatással lehet a társadalomra, a gazdaságra.

A kérdésekre kapott válaszok eredményeit a következő fejezetben ismertetjük.

\section{Eredmények és azok értékelése}

A migránsok foglalkoztatáshoz, munkavállaláshoz kötődő vizsgálatok során kíváncsiak voltunk arra, hogy a megkérdezettek hogyan viszonyulnak a migránsok munkaerőpiaci intergrációját érintő kérdésekhez, vagyis egyetértenek-e azzal, hogy a migráns személyek bekapcsolódjanak a munka világába. Az eredmények alapján egyértelműen negatív a hozzáállása a válaszadóknak ebben a kérdéskörben, mivel 61\%-uk elutasítja az integrációt. A válaszadók 32\% nyilatkozott pozitívan a kérdést illetően, míg mindössze $8 \%$ volt bizonytalan, illetve nem válaszolt.

Rákérdeztünk arra is, hogy a válaszadó félti-e a munkahelyét a migránsoktól. Az eredmények alapján a megkérdezettek 71\%-a nyilatkozott úgy, hogy nem fél attól, hogy a migránsok elveszik a munkalehetőséget, míg 28\% tart ettől. Két fő nem válaszolt a kérdésre. Az iskolai végzettség alapján az érettségivel rendelkező válaszadók féltik legjobban a munkájukat, akik közül 40\%-uk nyilatkozott úgy, hogy konkurenciát jelent számára a külföldi munkavállaló, a szakmunkások 24\%-a, míg a felsőfokú végzettséggel rendelkezők közül a főiskolai végzettségűek $22 \%$-a, az egyetemi diplomások mindössze 7\%-a aggódik a migránsok munkavállalása miatt. Kovács (2006) Szabolcs-Szatmár-Bereg megyében végzett kutatási eredménye alapján a válaszadók 56,45\%-a vélte úgy, hogy konkurenciát jelentenek a 
külföldiek a munkaerőpiacon a hazaiakra, leginkább az alacsony iskolai végzettségűek féltették a munkájukat.

Arra a kérdésre, hogy dolgoznának-e együtt migráns személlyel, a válaszadók több, mint fele (52\%) nyilatkozott bizonytalanul, vagyis nem tudja megítélni. A válaszadók 35\%-a egyértelmúen elutasítja a közös munkát (közülük több mint fele nyilatkozott úgy az előző kérdésnél, hogy félti a munkahelyét a migránsoktól). A vizsgált mintában szereplők mindössze 9\%-a dolgozna együtt szívesen migránssal.

Megkérdeztük, hogy szívesen lenne-e a válaszadó migráns kollégája szakmai mentora. Az adott kérdés azért merült fel bennünk, mert számos esetben a felmerülő munkaerőpiaci hiányt, ami gyakran a betanított munkásoknál jelentkezik, külföldi munkavállalókkal töltik fel. Ennél a kérdésnél már kevesebben voltak bizonytalanok, a válaszadók 39\%-a nyilatkozott úgy, hogy nem tudja megítélni, ugyanakkor a válaszadók fele nem szívesen végezne mentorálási tevékenységet. A válaszadók mindössze 7\% lenne szívesen mentor, vagyis azok közül, akik szívesen együtt dolgoznának velük, nem mindenki vállalná be a mentori feladatokat is.

A migránsok foglalkoztatásában szerepet játszó tényezőket a 3. ábra ismerteti. A válaszadóknak a felsorolt tényezőket 1-6-ig terjedő skálán kellett minősíteniük. Összességében az átlagértékek nem magasak, mindössze három állítás esetén figyelhető meg háromnál magasabb átlagérték. A válaszadók véleménye szerint a migránsok magyar nyelvtudása területén hiányosságok tapasztalhatók (4.51). Az eredmény alátámasztja, az Európai Migrációs Stratégiában (2015) megfogalmazottakat, miszerint kiemelten kell kezelni a képzettségek elismerését és a szakmai és nyelvi képzést, azaz a munkaerőpiaci hozzáférést. Az integrációnak kétirányú folyamatot kell jelentenie, amelyben a szociális partnerek, a helyi önkormányzatok és a civil társadalom is jelentős szerepet tölt be. A második legmagasabb átlagértéket $(3,48)$ a migránsok kevésbé igényesek a munkakörülményekre állítás kapta, míg mindössze két századdal mutat alacsonyabb átlagértéket az olcsóbb munkaerő. A legalacsonyabb átlagértéket az az állítás kapta, miszerint a migránsok alkalmazására a megfelelően képzett hazai munkaerő hiánya miatt van szükség. A minősítéseket megvizsgáltuk beosztás szerint is, de az összesített átlaghoz képest a rangsorban eltérés nem tapasztalható. A vezetők és beosztottak értékelése között mindössze néhány százados eltérés figyelhető meg. 
A migránsok tisztességesen és megbízhatóan dolgoznak.

A migránsok alkalmazását a kapcsolati háló hiánya nehezíti.

A migránsok alkalmazására a megfelelően képzett hazai munkaerő hiánya miatt van szükség.

A migránsok kevésbé igényesek a munkakörülményekre.

A migránsok ellátnak olyan munkákat, amelyekre a hazaiak nem vállalkoznak.

A migránsok hiányosságokkal rendelkeznek a magyar nyelv ismerete terén.

A belső munkaerő-mobilitás alacsony.

A migránsok olcsóbban dolgoznak.

A migránsok mobilabbak, így rugalmasabb kínálatot jelentenek.

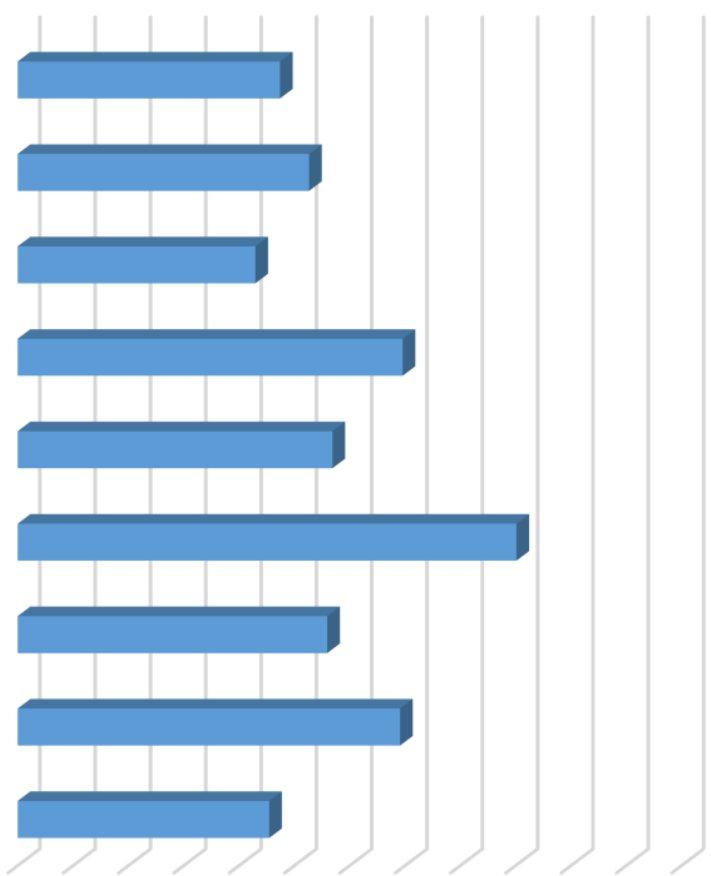

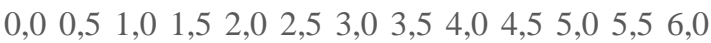

3. ábra A migránsok foglalkoztatásában szerepet játszó tényezők megítélése

(Forrás: Saját adatgyüjtés)

A migráns munkavállalók alkalmazásának pozitív és negatív hatásait is vizsgáltuk. A társadalomra gyakorolt pozitív hatásokra vonatkozó állítások értékelése viszonylag homogén. Valamennyi megfogalmazott állítás esetén a válaszadók 75-86\%-a 3-as vagy annál alacsonyabb minősítést adott meg az 1-6-ig terjedő skálán, vagyis a pozitív hatásokat kevésbé érzik meghatározónak a migránsok foglalkoztatásával (4. ábra).

$\mathrm{Az}$ átlagértékeket vizsgálva megállapítható, hogy a legmagasabbat az az állítás kapta, miszerint a migráns munkavállalók segítségével betölthetővé válnak a legkevésbé vonzó munkakörök, de ennek átlagértéke is mindössze 2,43. Az eredmények megerősítik a migránsok foglalkoztatásával szembeni negatív munkaerőpiaci attitűdöt, mivel az integráció pozitív hatásait nem érzik megalapozottnak a megkérdezettek. 
A migráns munkavállalók jelenléte hozzájárul az egyes gazdasági ágak fejlődéséhez.

A migráns vállalkozók megjelenésével hazai munkavállalók is álláshoz juthatnak

A migráns munkavállalók segítségével betölthetővé válnak a legkevésbé vonzó munkakörök.

A migránsok rugalmas munkaerőt jelentenek, ami használ a gazdaságnak

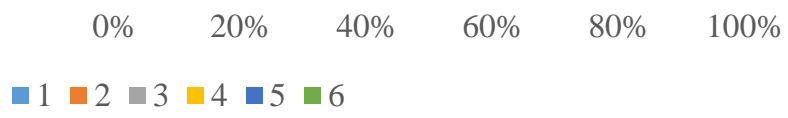

4. ábra A migráns munkavállalók alkalmazásának megítélése a pozitív hatások tekintetében

(Forrás: Saját adatgyüjtés)

A gazdaságra gyakorolt negatív hatások értékelésénél szintén 1-6-ig terjedő skálán kellett értékelni a válaszadóknak a felsorolt állításokat az alapján, hogy mennyire ért vele egyet. Az eredményeket az 5. ábra mutatja. Megállapítható, hogy a felsorolt állítások közül mindössze egy esetben, miszerint a migráns munkavállalók jelenléte konzerválja a rossz munkakörülményeket figyelhető meg egyet nem értés, vagyis a válaszadók 59\%-a 1-3 közötti értékelést adott.

A migráns munkavállalók jelenléte hozzájárul a bünözés növekedéséhez.

A migráns munkavállalók jelenléte fokozza a munkaerö-piaci diszkriminációt.

A migráns munkavállalók jelenléte növeli a hazaiak munkanélküliségét.

A migráns munkavállalók jelenléte hozzájárul az elöítéletek erősödéséhez.

A migráns munkavállalók jelenléte konzerválja a rossz munkakörülményeket.

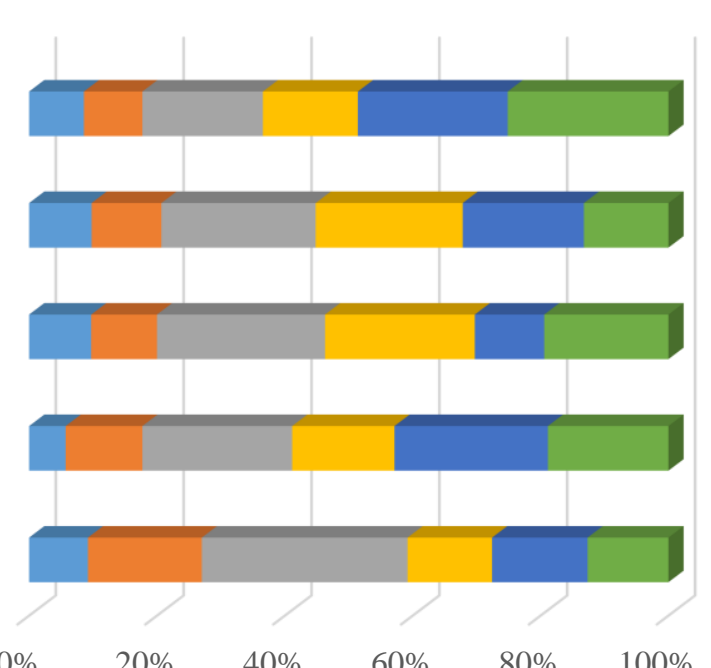

$$
\begin{aligned}
& \begin{array}{llllll}
0 \% & 20 \% & 40 \% & 60 \% & 80 \% & 100 \%
\end{array}
\end{aligned}
$$

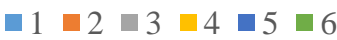

5. ábra A migráns munkavállalók alkalmazásának negatív hatásai a gazdaságra

(Forrás: Saját adatgyüjtés) 
A megkérdezettek a legnagyobb problémát a bűnözés növekedésében és az előítéletek erősödésében látják. Az előbbi állításnál a válaszadók 63\%-a, míg az utóbbinál a válaszadó 59\%-a adott 4-6 közötti értékelést. Ezzel összefüggésbe hozható az a tény is, hogy annak ellenére, hogy Magyarország nem elsőszámú célország, a politika, a média, a szóbeszéd hatására az emberek jelentős problémaként és veszélyforrásként élik meg a migrációs jelenséget [20]. Bár a válaszadók, ahogy azt korábban ismertettük, nem féltik a munkahelyüket a migránsoktól, véleményük szerint jelenlétük növeli a hazai munkavállalók munkanélküliségét, vagyis ebben az értelmezésben mégis elveszik a munkát a hazaiaktól, mivel a válaszadók 54\%-a adott 4-6 közötti értékelést.

\section{Következtetések}

A szakirodalmi feldolgozás alapján megállapítható, hogy a migránsok munkaerőpiaci integrációja a negatívumok mellett számos pozitív hatással járhat együtt, viszont ennek megvalósulása nagyban múlik a befogadó ország kultúráján, esélyegyenlőségi szemléletén, informáltságán, attitűdjén. A vizsgálati eredmények szerint a megkérdezett munkavállalók több mint fele nem ért egyet a migránsok munkaerőpiaci integrációjával, annak ellenére, hogy nem érzi konkurenciának a külföldről érkező munkavállalókat. Az egyértelmű elutasítás ellenére a közös munka lehetőségénél már bizonytalanság figyelhető meg a válaszadók között, mivel a megkérdezettek több mint fele nem tudta egyértelműen eldönteni. Ennek hátterében véleményünk szerint az információ és tapasztalathiány állhat. A migránsok foglalkoztatásának legfóbb okát az alacsonyabb bérezésben látják és a munkakörülményekkel szembeni alacsonyabb elvárásoknak tulajdonítják. Bár a szakirodalom a migrációs jelenség számos pozitív hatását kiemeli, a kutatási eredmények szerint a migráns foglalkoztatás társadalomra és gazdaságra gyakorolt hatását negatívan látják a válaszadók. Véleményük szerint erősödnek az előítéletek és a bűnözés, illetve a hazai munkanélküliség növekedését is előidézheti.

\section{Hivatkozások}

[1] Bördős K., Csillag M., Orosz A. (2015): A bevándorlás hatása a hazai munkavállalók munkaerő-piaci helyzetére Európában (3.1) In: Az Európába irányuló és 2015-től felgyorsult migráció tényezői, irányai és kilátásai. (szerk.: Csuka Gy. és Török Á.).A Magyar Tudományos Akadémia Migrációs Munkacsoportjának elemzése. Budapest, pp.46-47

[2] Dél-Alföldi Regionális Társadalomtudományi Kutatási Egyesület (2009): Biztos út a magyar munkaerőpiacra?! A bevándorlók munkaerőpiaci helyzete Magyarországon. Záró tanulmány, Szeged, 62.p.

[3] Dunai P. (2017): Migráns-minták. Figyelő, Budapest, pp.42-43.

[4] Európai migrációs stratégia (2015) Az Európai Gazdasági és Szociális Bizottság véleménye, SOC/525, $\quad$ Brüsszel, $2015 . \quad$ december 10. https://webapi.eesc.europa.eu/documentsanonymous/EESC-2015-04319-00-00-AC-TRAHU.docx 
[5] Eurostat (2016): A migrációra és a migráns népességre vonatkozó statisztika, 2016. május http://ec.europa.eu/eurostat/statistics-

explained/index.php/Migration_and_migrant_population_statistics/hu

[6] Gergely É. (2015): "Gátló tényezôk" feltárása a szervezetek teljesítménymenedzsment folyamatában. Taylor: Gazdálkodás- És Szervezéstudományi Folyóirat: A Virtuális Intézet Közép-Európa Kutatására Közleményei VII. évfolyam 3-4. sz. (No20-21) pp. 98-206.

[7] Gyimóthy É (2008): Mire ügyeljünk a bevándorlók foglalkoztatása során? 2008. 07.18. https://www.hrportal.hu/hr/mire-ugyeljunk-a-bevandorlok-foglalkoztatasa-soran20080718.html

[8] Gyulai G. (2014): Külföldiek Magyarországon. Magyar Helsinki Bizottság, Budapest, 32.p. http://helsinki.hu/wp-content/uploads/kulfoldiek-magyarorszagon_helsinkibizottsag.pdf

[9] Hárs Á. (2009): Nemzetközi migráció a számok és a statisztika tükrében. Statisztikai Szemle, 87. évfolyam 7-8. szám, pp.682-711.

[10] Hárs Á. (2010.): Migráció és munkaerôpiac Magyarországon. In: Változó migráció - változó környezet (szerk.: Hárs á., Tóth J.), MTA Etniaki-nemzeti Kisebbségkutató Intézet, Budapest, pp. 15-54.

[11] Hárs Á. (2015): A migráns népesség jellemzői a népszámlálás alapján (3.4) In: Az Európába irányuló és 2015-től felgyorsult migráció tényezői, irányai és kilátásai. (szerk.: Csuka Gy. és Török Á.).A Magyar Tudományos Akadémia Migrációs Munkacsoportjának elemzése. Budapest, pp. 50-51.

[12] Juhász Cs. (2010): A vezetők humán erőforrásokkal szembeni elvárásainak változása. A Virtuális Intézet Közép-Európa Kutatására Közleményei II. évf. 3-4, Szeged, pp. 94-102.

[13] Juhász J., Makara P., Makara E. (2011): A munkaerő-piaci integráció kihívásai Magyarországon - A harmadik országbeli munkavállalók beilleszkedésének esélyei és korlátai. Kutatási Zárótanulmány, Pantha Rhei Társadalomkutató Bt., Budapest, 2011. június, pp. 37-39.

[14] Kincses Á. (2015): A nemzetközi migráció Magyarországon és a Kárpát-medence magyar migrációs hálózatai a 21. század elején. Központi Statisztikai Hivatal Műhelytanulmányok 8. Budapest, 88.p. ISBN 978-963-235-484-2

[15] Kisfalusi D. (2012): A bevándorlók szociodemográfiai jellemzői, kulturális és társadalmi erőforrásokkal való ellátottsága, migrációs céljaik és motivációik. In: Bevándorlók a magyar társadalom tükrében: méltóság, igazságosság és civil integráció. (Szerk.: Göncz Borbála, Lengyel György, Tóth Lilla), Budapesti Corvinus Egyetem, Budapest, pp.19-60.

[16] Kovács K. (2006): A nemzetközi migránsok fogadtatása Magyarországon, különös tekintettel Szabolcs-Szatmár-Bereg megyére. Doktori (PhD) értekezés, Debreceni Egyetem, Természettudományi Kar, 179.p. 
[17] Kováts A. (2013): Bevándorlók integrációja Magyarországon korábbi kutatások adatai alapján. In: Bevándorlás és Integráció - Magyarországi adatok, európai indikátorok (szerk.: Kováts András), Budapest, pp. 25-41.

[18] Lévai I. (1997): Nemzetközi migráció és menekültpolitika. In: Migráció és Politika (szerk.: Sik E. és Tóth J.)

[19] Pakurár, M. - Cehla, B. - Oláh, J. - Nábrádi, A. (2013): Employment Characteristics of Ukrainian Citizens in Hungary, Apstract - Applied Studies in Agribusiness and Commerce, 7(4-5) pp.113-120.

[20] Pierog A.- Szabdos Gy. N. (2016): Migránsok, civilek, szervezeti lehetőségek- civil szervezetek a migránsokért, a migránsok által. In: Migránsok, menekültek, új hazát keresők. (Szerk.: Papp K., Kerepeszki R.): Debrecen: Erdély-történeti Alapítvány; Debreceni Egyetem Történelmi Intézete, 2016. pp. 253-264. (Speculum historiae Debreceniense) (ISBN:978963-473-942-5)

[21] Piore, M. J. (1979): Birds of Passege: Migrant Labour in Industrial Societes. New York, Cambridge University Press

[22] Rédei, M. (2005): A nemzetközi vándorlás folyamatának irányítása. Statisztikai Szemle. 83. évf. 7. sz. pp.662-680.

[23] Simon, J. L. (1984): Immigrants, Taxes and Welfare int he United States. Population and Development Review Vol. 10. No. 1. (March 1984) pp. 55-69.

[24] Szű́cs E., Kovács S., Tornai E., Takács T., Matkó A. (2014): A munkahelyi stressz vizsgálata. Társadalomkutatás 32:(4) pp. 384-401. 